\title{
Amitav Ghosh's The Circle of Reason: A Clash between Superstition and Scientific Reason
}

\author{
Gyanabati Khuraijam \\ NIT Agartala, India \\ Yumnam Oken Singh \\ JNV Ukhrul, Manipur, India
}

\section{Introduction:}

Life in the modern world is made of myriad impressions and we find various types of people having their own way of reasoning on certain things. Some people strictly follow the scientific temper while others are still preoccupied with the traditional beliefs imbibed with the characteristics of ignorance and superstitions. The latter type of people are so deeply engrossed in their superstitious beliefs that they have totally lost all the scientific reasoning power and start having a blind faith on any traditional practice. This type of contradictory beliefs often brings about clashes amongst the people. And this very fact is clearly presented in Amitav Ghosh's debut novel, The Circle of Reason, whichmarks "a break from the traditional themes of the Indian English novel and structure of the well-made novel" (Rao 31). In fact, it can be taken as the beginning of the entire generation of new writers who came up in the 1980s, often termed as "Ghosh Generation of writers"(Advani 17) or "Stephanians"(Trivedi4) who have left an enduring impression in the novels of the eighties giving a new turn and meaning tothe Indian English fiction.

The novel is a journey from Satwa (Reason) to Rajas (Passion) to Tamas (Death). Symbolically, it deals with the three phases of human life. Satwaembodies the quest forwisdom, Rajassignifies the life of passion and Tamasrepresents darkness and devastation. Claire Chambers says that it "closely examines philosophies of reason, and the science and technology that is associated with these philosophies" (37-38). The concept of reason is closely associated with many characteristics like the proficiency to contemplate rationally, the capability of making the proper judgement between right and wrong, bringing about the scientific temper and making the place free of superstition, a liberal attitude and civilized way of life. According to Popkin and Stroll, reason may be defined as a set of inductive methods that helps one attain "knowledge in the strongest sense, knowledge that 
can under no circumstances be false" (Popkin 239).The very concept of reason itself brings people all over the world together and connects them. Claire Chambers writes:

The notion that science is a product of history and society is affirmed in The Circle of Reason's examination of two contrasting groups of scientific practitioners that Balaram admires. Firstly, the novel's portrayal of the mainstream science of Louis Pasteur and others suggests that a perception of science as consisting of a series of groundbreaking discoveries made by great men, is misleading. Secondly, Ghosh interrogates the equally false assumptions that surround the so-called 'pseudo-scientists', whose theories are judged by history to have failed. The novel invites us to consider many pseudo-scientific practices, such as Lambroso's criminology, phrenology, and the plant physiology of Jagadish Chandra Bose. (42)

\section{Scientific Reason versus Logic:}

The main focus of the paper is in the characters of Balaram and Alu - two characters in the novel who are obsessed with scientific reason. The perfect example of a person with dominant scientific reason is seen in the character of BalaraminLalpukur village in the first part of the novel. He is a rationalist and is fully influenced by Life of Pasteur, which was given to him by his friend Gopal.Though Ghosh calls Balaram a rationalist and a believer in science and reason, he acts in a very irrational way. His interest in the Vallery-Radot'sLife of Pasteur, Practical Phrenology and the Rationalists' society is termed as "A Pasteurized Cosmos" in the novel (35).Being an enthusiastic student of phrenology, he is always busy measuring the size of heads with a huge pair of callipers thereby making solemn predictions. He considers Pasteur his model and shapes his life with a scientific temper and nationalistic outlook since his very childhood. He says that he is interested in Phrenology because he feels that this field of study would act as a bridge between science and personality. The great importance of science in one's life is emphasised when he expresses his feelings to his friend Gopal:

Don't you see? ... In this science the inside and the outside, the mind and the body, what people do and what they are, are one. Don't you see how important it is? (17)

Having such a strong obsession with Phrenology, he spends "all his spare time measuring and examining people's heads" (3) and discovers the various bumps on people's heads ultimately drawing the conclusion that these very bumps define and 
confirm the behaviours of the individuals. In short, the 'science' of phrenology seems to act as a reliable source to forecast the personality trait of an individual and it gives him profound satisfaction. He has been obsessed with this illogical reasoning since the time he had found "the copy of Practical Phrenology... in a second hand bookshop in College Street" (14). Balaram is so excited at exploring the shape of his nephew's skull that he is immediately named Alu (potato) for he says, “... It's an alu, a potato, a huge, freshly dug, lumpy potato" (3). Balaram makesscientific findings after observingpeople's behaviour rather than collecting data and formulating a theory after the finding. For example, Balaram notices Bhudeb Roy's "organ of secretiveness" (10) only after it has been discovered that he is spying on local people and reporting to the police. In an indictment of scientific methodology as a whole, Gopal thinks to himself, "...the trouble with people like Balaram was that theories came first and the truth afterwards" (13). In this context, the following statement by Stephen Jay Gould is illuminating and worth quoting:

Science is rooted in creative interpretation. Numbers suggest, constrain, and refute; they do not, by themselves, specify the content of scientific theories. Theories are built upon the interpretation of numbers, and interpreters are often trapped by their own rhetoric. They believe in their own objectivity, and fail to discern the prejudice that leads them to one interpretation among many consistent with their numbers. (74)

The inspiration from the work of Louis Pasteur is so immense that he starts predicting the personality traits of the small child of Bhudeb Roy because of which his family faces lots of disadvantages:

...your son, has distinct protuberances above the asterion and over the temporal muscles above its ears... his mandible and zygomatic arches are already developed to so extraordinary a degree... that he reproduces almost exactly the structure of the Typical Homicidal... pray that you may not be his first victim. (24)

The next morning, his wife Toru-devi finds "that six of their coconut palms had been axed and all their lemon trees uprooted" (24). Another incident bringing misfortune to him is when he interfered during the Saraswati Puja organized by Bhudeb Roy in which public officials and a priest have been invited. Balaramnoticeda growing cranial lump on the figurine of Saraswati, the Goddess of Knowledge which is caused by the heat of the lights inside the image's head. Then he jumped up onto the statue's platform and ripped off its head, declaring it to be 
Vanity, rather than Knowledgedue to which the ceremony had to be called off. The whole incidentbrought unwanted conflict between science, the sacred and religion.

The result is that the next morning his wife finds their pond covered with poisoned fish. Toru-devi gets fed up with all these and she takes out all his books from the library to the courtyard, sprinkles "kerosene over the huge mound of books" (33) and burns them down.ButBalaram still remains unaffected and again makes an attempt to clean the surrounding area in his village Lalpukur with carbolic acid to disinfect the whole area from germs which indeed succeeded in saving many lives. Unfortunately,the Bangladesh war of independence breaks outbefore he could complete his whole task.He runs out of money and could not continue with his mission. Not only this, Jyoti Das, the Superintendent of Police intervened enquiring from where he got the money for carrying out the whole process of disinfecting the entire village with carbolic acid. Again, Balaram applies his scientific reason as to why the plane had to crash in their village during the war. He had an argument with the version of Gopal that it is by sheer chance that it happened, saying:

If it has no meaning, why would it happen? Of course, it has a meaning, but the meaning must be read rationally - not with the hocus-pocus of these Stone Age magicians. (87)

At the same time, people in the village start to predict certain things on this issue and they even conclude that "the plane had conceived the child" (98) in Parbotidevi, Bhudeb Roy's wife and all the barren women in the village should start worshipping her so that they are also blessed. Later on, when the child is born, Parboti-devi even tries to take her daughter to the site where the plane crashed with the belief that it would improve the strength and health of her daughter.

Balaram's obsession withthe philosophy of Pasteur takes him towards barbarism rather than reasoning - contradicting "the Rationalists' motto 'Reason rescues Man from Barbarity," (46) and Gopal deeply regrets lending him that book for it turned "into a weapon against him" (46).Both of them have different philosophies and ways ofreasoning, and when Gopal points out his obsession withthe shapes of the cranial skulls, he retorts:

Science does not belong to countries. Reason does not belong to any nation. They belong to history - to the world. (54)

He leaves and remainsaloof from any contact and when he comes back after a span of eight months, he announces happily that he has made Alu a weaver. This very news leaves Gopal astonished "with disbelief at the thought of an educated, literate 
man pushing his own nephew to manual labour" (54). When he is asked the reason, his reply shows the extent of his obsession withPhrenology:

It was the lump on his forehead beneath the hair-line... the organ that made a mere two-legged creature Man, the seat of Reason.... His intuition was proved right in every detail: Alu's body, his hands, his legs, his arms, not to speak of the Organ, corresponded exactly to his calculations of the proportions ideal for a weaver. (55)

In fact, Alu's extraordinary ability embodies the prospectiveweaverand Balaramfurther explains:

Man at the loom is the finest example of Mechanical man; a creature who makes his own world as no other can, with his mind. The machine is man's curse and his salvation, and no machine has created man as much as the loom. It has created not separate worlds but one, for it has never permitted the division of the world. The loom recognizes no continents and no countries. It has tied the world together with its bloody ironies from the beginning of human time ... It has never permitted the division of reason. (55)

He further continues his philosophy of weaving and says:

Weaving is hope because it has no country, no continent.

Weaving is Reason, which makes the world mad and makes it human. (58)

This inspiration of Life of Pasteur is so immense that even during his college life at the Presidency College in Calcutta, as President of the Society for the Dissemination of Science and Rationalism, he had induced his classmates to follow Pasteur's principles of hygiene and as a first step he decided to wage a campaign against dirty underwear. Seeing the reluctance of his fellows, he explains:

All we want to do is make people think. And what better place to begin with than the body and its clothing? No one can turn his back on his body and his own clothes. If only we can sow the germ of a question in their minds, their own clothes and limps will do the rest for us. They will become daily reminders, daily pinpricks, to shake them out of their smugness. (103)

Dantu surprisingly reacted in a realistic manner to such a type of reasoning and questions Balaram: 
What good will it do anyone if the students of this college begin to wash their underwear not only every day, but also every hour? Will it make any difference to anyone? Dirt does not lie in underwear. It is the world, the world of people, which makes dirt possible. How can you hope to change people's bodies without changing the world? (104)

To this, Balaram gives a grave reply in his own way:

Why do we always think of changing the world and never of changing people? Surely, surely, if we succeed in making even one person, just one, ask of himself how I can be a better, cleaner human being, we will have changed the world, changed it in the best of possible ways. (104)

He was finally able to persuade his reluctant fellows and even gave a catchy name to it as "The Campaign for Clean Clouts" (105).But the campaign was brought to an abrupt close when some bullies at the college proposed at a meeting to inspect his underwear, and he ran away- breaking his legs. Moreover, he did not like the idea of checking his own dirty underwear, as he would have been embarrassed to stand in front of everyone. This is the first of several occasions in the novel when muscle power overcomes reason.

Balaram again conceives an idea of starting an organization in Lalpukur 'The School of Reason', just as Bhudeb Roy closes down the school, to provide practical skills as well as some conventional subjects to everyone irrespective of caste, gender, or age, thusshowing preference for the illiterate folks. He had a well-carved out plan for the school:

The School would have two main departments...one the Department of Pure Reason and the other the Department of Practical Reason: abstract reason and concrete reason, a meeting of the two great forms of human thought... In the Department of Pure Reason they would be taught elementary reading, writing and arithmetic, and they would be given lectures on the history of science and technology... In the Department of Practical Reason, the students would be taught weaving or tailoring... (107)

Further plans are being carried out and the School turns out to be a great success and starts earning lots of money. Balaram further plans to expand the school with another department - the Department of the March of Reason to remind them of 
another aspect - Reason Militant. It seems thatBalaram and Bhudeb Roy, with so many opposing fascinations are coming to a common point for the first time, i.e. serving society for a good cause by imparting educationand skill though it is for a brief period. But he still insists ondisinfecting the village thoroughly with carbolic acid so that "no trace of a corrupting germ would surface in it again" (117).Their ideas never go together and it took no time for the conflict to reach the peak point and everything was turned to ashes when the fire broke out. It is the rationalistic and scientific mind of Balaram that brings about his destruction and death. Pasteur had discovered a life-saving drug but Balaram'sobsessiveknowledge brings him to his own end.With this, Ghosh presents the folly of obsession with Western scientific reason.

Balaramhas alwaysbeen in favour of the scientific reason, but as we know that a society comprises all types of people with different types of thinking and logic, he is frequently challenged by other voices. His friend Gopal always contradicts his idea concerning the practice of reason he found in Practical Phrenology saying that "this looks like rubbish" (17) and views it as a source of power, that "even Reason discovers itself through events and people" (38). Gopal strongly feels that scientific reason is a product of history and society andfully supports the arguments of modern sociologists and historians of science. Here, it is worth quoting Michel Foucault seeking to place reason in a particular time and space:

What reason perceives as its necessity, or rather, what different forms of rationality offer as their necessary being, can perfectly well be shown to have a history ..., Which is not to say, however, that these forms of rationality were irrational. It means that they reside on a base of human practice and human history; and that since these things have been made, they can be unmade... (37)

Precisely, Gopal is more rational and practical in his outlook on everything. In a meeting, he clarifies the object of the Rationalists saying:

Their aim [is] the application of rational principles to everything around them - to their own lives, to society, to religion, to history. (46)

After reading the Sanskrit scriptures, he realises that there are definitely some "curious parallelisms between the ideas of the ancient Hindu sages and modern science" (46-47). But people have been duped and cheated in the name of religion for a long time as they start believing whatever the priests and Brahmins say. So, he thinks it necessary to make the masses of the society aware of "how they were 
daily deceived and cheated by the self-styled purveyors of religion" (47). It is due to the ignorance of the people and due to their lack of reasoning that they have been easily deceived in the name of religion for a long time. This very practice and belief has also been shown in the Bollywood movie $O M G$ - Oh My God!in which the lead role played by PareshRawal as Kanji Lalji Mehta, a middle class atheistHindu, tries to show the illogicality behind the blind faith and religious practice of every individual in the society.People easily get enchanted with any supernatural story behind a statue. Taking advantage of such blind faith and belief, he makes a lot of profit selling the idols of God. Though there is serious criticismagainst the movie, it cannot be denied that it is full of practical reasoning set against the ageold illogical practice doomed with ignorance and superstition.

The illogical reasoning of Balaram can be seen again in the way he replies when Alu expresses his desire to get married:

That's a big business. We must set about it scientifically. We have to think about the right personality types and things like that. We can't set about it in a hurry... It takes a lot of work. You'd better talk to your aunt... Perhaps she could advertise in the newspaper... (112)

His confidence in the power of scientific rationality is not merely eccentric, since the rationalist thinkers in the colonial world also shared the similar kind of confidence though in a logical way. Pt. Jawaharlal Nehru, in hisThe Discovery of India, writes:

I am convinced that the methods and approach of science have revolutionized human life more than anything else in the long course of history, and have opened doors and avenues of further and even more radical change, leading up to the very portals of what has long been considered the unknown. (17)

This very faith in science has indeed acted as a catalyst in setting up the Department of Science and Technology in independent India. This vision is also clearly reflected in Balaram'spractice of scientific reason.He dreams to establish a better society free of germs and diseases for the betterment of the humankind as, in the words of Anthony Burgess,Balaram "stands, in his demented way, for progress" (Burgess 6). He is trying to do away withthe ills of the society just as Jawaharlal Nehru and Rammohan Roy attempted to bring about a progressive, rational programme of social transformation. Balaram is so firm in his belief in scientific reason that he cannot look beyond it and cannot accept things, which go against the principles of Louis Pasteur. And this very illogical trait in him is 
responsible for the failure of his plans leading frequently to the unnecessary arguments and unwanted enmity with his friend Bhudeb Roy and others in the village as well as in the college, ultimately ending up his life.

\section{Carbolic Acid (Science) versus Ganga Jal (Superstition):}

Throughout the novel, we see different forms in which the cleansing programmes are carried out.In al-Ghazira, Hajj Fahmy makes Adil and his cousin bathe in antiseptic.Alu, who is fully inspired by his uncle, Balaram, uses carbolic acid in every cleansing programme.Mrs.Vermauses carbolic acid instead of 'Ganga Jal' to sanctify the dying person. Dr. Mishra remarks, "carbolic acid has become holy water" (Ghosh 411). To this Mrs.Verma replies:

What does it matter whether it's Ganga Jal or carbolic acid? It's just a question of cleaning the place, isn't it? People thought something was clean once, now they think something else is clean. What difference does it make to the dead, Dr. Mishra? (411)

In a way, Mrs. Verma has some logic in it and the above view has been put forth in the following way by Shubha Tiwari:

Ghosh is of course pointing out to the blind faith of millions of Indians in Ganga Jal even though the water of the life-giving river is so badly polluted. (17)

In fact, people are so blindfolded in the belief of the age-old tradition that they have lost all the logic to think what is right and what is wrong. For them, the long practised tradition that a dying man is to be given Ganga Jal with the belief that it wouldrelieve him of all the sins he has done in his life is still acting as a stronghold without applying the logic that the polluted water will quicken hisdeath. It is indeed disheartening to realize that the reasoning power of the people receives a defeating blow as the course of action goes in an irrational line and hereGhoshalso states in the novel that:

... without the germ 'life would become impossible because death would be incomplete.' (396)

Again, the pasteused inPujaat Kulfi's death should have been made of ghee but it is replaced with carbolic acid. So, carbolic acid is used again and again to carry out the cleansing and purification activities. Regarding Ghosh's use of this cleansing agent again and again,Shubha Tiwarisays: 
At times, I feel, The Circle of Reason is simply a response of Amitav Ghosh to the unhygienic conditions of India. It is a complex response of the author at appalling dirt and filth in a land whose people have always talked of purity of soul as well as surroundings. The contradiction is fascinating. People insist on taking morning baths, purifying their homes with havans (fire) and keep fasts for internal cleansing. And still, they turn a blind eye to all the garbage and dirt in their holy rivers and holy places. (18)

But Balaram fails in his attempt to educate the village youths to think rationally. His knowledge of Science and his faith in Reason have nobase in real life situations. Though his ideas are beautiful, he is illogical and impractical. In other words, he was trying to assign the abstract ideas to everything and everyone, forgetting the fact that knowledge without worldly wisdom is likely to bring about disaster. Balaramalong with many people around him and their belongings are engulfed by the fire that breaks out. The fire was caused by none but Balaram's plan of attack on Bhudeb Roy with the help of Rakhal. It is only his folly and illogical actions that lead to his ultimate doom.

We generally tend toreject reasonthat involves the creative use of the intellect in everyday practices.Balaram's nephew Alu remains trapped under the debris of the shopping complex 'The Star' for four days after it collapsed due to adulterated cement and herealizes the truth behind scientific reasoning that money is the parasite infecting the healthy society. He then begins to speak at length about Louis Pasteur, about dirt and cleanliness. Alu then proposes:

We will drive money from the Ras, and without it we shall be happier, richer, more prosperous than ever before. (281)

The characters in the novel go through all kinds of sufferings and they struggle a lot and wander from place to place to save their lives.

\section{Conclusion:}

The article focuses on the obsessive nature of Balaramafter hisreading ofLife of Pasteur. His obsession with scientific reasoning and the illogical practice of Phrenology are responsible for his ultimate doom and the disaster in his family. This is due to the lack of proper scientific knowledge and his blind obsessionwith science without applying much logic. His mind is fully obsessed with the teachings of Pasteur that he fails to ponder on the activities he carriesout. So, he has the 
tendency to amalgamate science with history and accentuate scientific knowledge. Ghosh describes his nature in the following words:

He had his own version of Calcutta. For him it was the city in which Ronald Ross discovered the origin of malaria, and Robert Koch, after years of effort, finally isolated the bacillus, which causes typhoid. It was the Calcutta in which Jagadish Bose first demonstrated the extraordinarily life -like patterns of stress responses in metals; where he first proved to a disbelieving world that plants are no less burdened with feeling than man. (41)

In fact, the development of scientific reasoning in the nineteenth-century India had a deep impact onBalaram. He starts cultivatinga theory that the beginning of the modern age was possible only because Pasteur had initiated the task of disinfecting the surroundings to maintain hygiene and inoculation for the well-being of the people, and because Madame Curie had undertakena series of experiments to start radiationtherapy to controlcancer cells. Balaramhas a firm belief that with the development and advancement in the field of scientific discoveries, the life of the people have become better and they are free of the age-old practice of superstition and, at the same time, they start having a scientific outlook on everything. Contradicting this belief, the following words of Louis James are worth quoting:

...Balaram's concepts of the 'new science' were already out of date, Curie and Pasteur being both creators of a new consciousness and the inheritors of the old....For Balaram's reliance on a nineteenth-century pseudo-science, Phrenology, in fact approximates to the Indian 'superstition' of popular religion and astrology that he opposes. His search for a new Western vision of reality, reflected in the chapter titled "a Pasteurised universe", brings to mind the Vedic legend of the creation of the world, in which the milk ocean of creation was churned by the gods and demons using a snake to separate the poison from the "amrit" (ambrosia). Shiva drank the poison, purifying (pasteurising) the universe. However the outcome was that only the gods drank the "Amrit": Ghosh suggests Balaram also has a one-sided strategy. (54)

The question is whether ignorance and superstition, which still prevail today in such a developed stage of our society, go away with education of the people in the society. There is no doubt that science has developed by leaps and bounds but people are still deeply engrossed in the age-old practice and frequently try to connect things/incidents/happenings with the existing superstitious beliefs. Howevereducated a person is, however developedthe world is and however- 
advanced the science is, people will always be moving on together carrying out the same practice for a long way; when such things would come to an end remains unpredictable. What matters is the mentality and attitude of the people. Tiwari relates it to the educational system in this way:

How should our children be educated? What should they be taught? Education is one big question that haunts the author. Education is memorization of facts at one level. At another, it is a tool to get a livelihood. At yet another, it sharpens human sensitivities. It kindles social consciousness in children. Can education uplift living standards of Indian masses and save them from nightmarish depths of poverty, ignorance and disease? ... So 'glimpse into the life of mind' is all that education should do. ... Ghosh seems to suggest a pattern where children are trained on rational patterns. They may enjoy their training. Their curiosity is not suffocated by authority. Their natural impulse to ask questions is encouraged. They are trained to find their own answers. (19)

So, the way of education imparted needs immediate attention for the betterment of lives so that the wrong implications are not carried out further and more focus should be given to the practical issues rather than the theoretical things. Moreover, Ghosh's portrayal of Balaram and his quest for scientific reasoning suggests that scientific knowledge alone is not enough and that the way of scientific approach and reasoning matters.

\section{References and notes:}

Advani, Rukun. "Novelists in Residence."The Fiction of St. Stephen's.ed. Aditya Bhattacharjea, Lola Chatterjee.New Delhi: Ravi Dayal Publisher. 2000. 8-20.

Burgess, Anthony. "A Little Dementia In The Nameof Progress." Review of The Circle of Reason. New York Review of Books. 6 July 1986: 6.

Chambers, Claire."Historicizing Scientific Reason in Amitav Ghosh'sThe Circle of Reason. "Amitav Ghosh: A Critical Companion.ed. TabishKhair. Delhi: Permanent Black. 2005. 36-55.

Foucault, Michel.“"Critical Theory/ Intellectual History."Politics, Philosophy, Culture: Interviews and Other Writings, 1977 - 1984. ed. and intro. Lawrence

D.Kritzman.trans. Alan Sheridan and others. New York: Routledge, 1988.17-46.

Ghosh, Amitav. The Circle of Reason.New Delhi: Ravi Dayal Publishers, 1986.

Gould, Stephen Jay. The Mismeasure of Man. Harmondsworth: Penguin, 1981.

James, Louis. "Shadow Lines: Cross-Cultural Perspectives in the Fiction of Amitav Ghosh." The Novels of Amitav Ghosh.ed. R. K. Dhawan. New Delhi: Prestige Books, 1999. 
Popkin, Richard H. and Avrum Stroll.Philosophy. Oxford: Made Simple, 1993.

Rao, K. Damodar. "Magic and Irony as Principles of Structure: A Reading of the Circle of Reason." The Novels of Amitav Ghosh. ed. R. K. Dhawan. New Delhi: Prestige Books, 1999.

Rawal, Paresh, perf. $O M G$ - Oh My God! Dir. Umesh Shukla.Viacom 18 Motion Pictures, 2012.Film.

Tiwari, Shubha. Amitav Ghosh: A Critical Study. New Delhi: Atlantic Publishers. 2003.

Trivedi, Harish.“The St. Stephen's Factor."The Fiction of St. Stephen's.ed.Aditya Bhattacharjea, Lola Chatterjee. New Delhi: Ravi Dayal Publisher. 2000. 3-7.

\title{
Summary
}

\section{Amitav Ghosh's The Circle of Reason: A Clash between Superstition and Scientific Reason}

\author{
Gyanabati Khuraijam \\ NIT Agartala, India
}

\author{
Yumnam Oken Singh \\ JNV Ukhrul, Manipur, India
}

In the modern world today, when some people apply logic and reasoning on certain things, other people are still dominated by the age-old practice of superstitious beliefs and it sometimes becomes difficult to accept the principles and works carried out by them. These contradictions often lead to clashes between them. Amitav Ghosh's Balaramin the Circle of Reason becomes obsessed with scientific reasoning after readingLife of Louis Pasteur and Practical Phrenology. The development of science and technology is taking place at such a fast pace but he starts carrying out all types of irrational activities like campaign for cleanliness of underwear in the name of scientific reasoning due to which his family faces many unwanted incidents; and his own actions leadto his doom. The existence of such contrasting characters in the society makes us ponder upon the reason behind it, and question the roles of education and experience in eradicating the ills of the society.

Key Words: scientific reason, phrenology, superstition, carbolic acid, logic, criminology. 